\title{
Expression of RET is associated with Oestrogen receptor expression but lacks prognostic significance in breast cancer
}

\author{
Robert Mechera ${ }^{1 \dagger}$, Savas D. Soysal ${ }^{1 * \dagger}$, Salvatore Piscuoglio ${ }^{2}$, Charlotte K. Y. Ng$^{2}$, Jasmin Zeindler ${ }^{1}$, Edin Mujagic ${ }^{1}$, \\ Silvio Däster ${ }^{1}$, Philippe Glauser ${ }^{1}$, Henry Hoffmann ${ }^{1}$, Ergin Kilic ${ }^{3}$, Raoul A. Droeser ${ }^{1}$, Walter P. Weber ${ }^{1}$ and \\ Simone Muenst ${ }^{2}$
}

\begin{abstract}
Background: The Rearranged during Transfection (RET) protein is overexpressed in a subset of Estrogen Receptor (ER) positive breast cancer, with both signalling pathways functionally interacting. This cross-talk plays a pivotal role in the resistance of breast cancer cells to anti-endocrine therapies, and RET expression is assumed to correlate with poor prognosis based on findings in small patient cohorts. The aim of our study was to investigate the impact of RET expression on patient outcome in human breast cancer.

Methods: We performed an immunohistochemical analysis of RET protein expression on a tissue microarray encompassing 990 breast cancer patients and correlated its expression with clinicopathological parameters and survival data.

Results: Expression of RET was detected in 409 out of 990 cases (41.3\%). RET and ER expression significantly correlated $(p<0.0001)$. The Luminal B HER2-positive subtype showed the highest expression rate (48.9\%). In univariate and multivariate survival analyses, RET expression had no impact on overall survival.

Conclusion: We confirmed the co-expression of RET and ER, but we did not find RET expression to be an independent prognostic factor in human breast cancer. Clinical trials with newly developed RET inhibitors are needed to evaluate if RET inhibition has a beneficial impact on patient survival in ER positive breast cancer.
\end{abstract}

Keywords: RET, Breast cancer, Oestrogen receptor, Endocrine resistance, Tissue microarray

\section{Background}

The Rearranged during Transfection (RET) protein belongs to the receptor tyrosine kinase (RTK) superfamily encoded by the RET gene on the human chromosome 10q11.2 [1]. Ligands of the $\mathrm{E}$ glial cell line-derived neurotrophic factor (GDNF) family of growth factors bind to one of four GDNF family $\alpha$-receptors (GFR $\alpha 1-4)$ leading to RET dimerization and trans-phosphorylation of intracellular tyrosines [2], which in turn regulate cellular differentiation, survival, proliferation, migration and chemotaxis [1]. The first causative oncogenic role of the RET gene was identified in human

\footnotetext{
* Correspondence: Savas.Soysal@usb.ch

${ }^{+}$Robert Mechera and Savas D. Soysal contributed equally to this work.

'Department of Surgery, University Hospital Basel, Spitalstrasse 21, 4031 Basel, Switzerland

Full list of author information is available at the end of the article
}

papillary thyroid carcinoma (PTC) [3-5]. Moreover, RET seems to also play a role in many other cancer entities and cancer syndromes [6-15].

The concept of activated receptor protein kinases in breast cancer has been well established, as overexpression or amplification promotes tumour growth [1,7-10]. With regard to RET, results have been initially conflicting $[11,12]$. However, RET has been increasingly gaining attention [13], and overexpression of RET and its coreceptor GFR 1 was demonstrated in a subset of hormone receptor positive breast cancers [4]. Moreover, a functional interaction between the RET and ER signalling pathways has been shown in breast cancer cell line studies $[6,14]$ : First, oestrogen stimulation seems to highly upregulate RET and GFR $\alpha$ mRA, suggesting that RET and GFR $\alpha$ are direct target genes of oestrogen signalling [6]. Secondly, RET activation has been 
demonstrated to increase $\mathrm{ER} \alpha$ phosphorylation as well as ER-independent transcriptional activation of $\mathrm{ER} \alpha$ target genes [14], leading to an increased oncogenicity and potentiation of oestrogen-driven proliferation [6].

The molecular mechanisms involved in the cross-talk between upstream kinases and $\mathrm{ER} \alpha$ play a pivotal role in the resistance to anti-endocrine therapies $[1,14,15]$ and RET expression seems to be associated with disease recurrence after adjuvant Tamoxifen treatment [14]. An additional mechanism of RET in endocrine resistance is the interaction with inflammatory cytokines. RET expression increases interleukin (IL)-6 levels in the presence of endocrine treatment, resulting in a positive-feed forward loop [16]. Due to the important role of IL-6 in breast cancer cell migration, RET not only seems to have an impact on tumour growth but also on metastasis $[16,17]$.

Supported by the association of RET expression and poor prognosis [15-17] as well as an association with negative prognostic factors such as large tumour size [16], the combination of endocrine therapy with agents blocking the RET signalling pathway could be a possible approach to overcome endocrine resistance in breast cancer, and has become the subject of preclinical research and various clinical trials $[1,15,18,19]$. Several preclinical studies have shown at least a partial reversibility of endocrine resistance in vivo and in vitro with RET inhibitors [15, 18-20]. However, early clinical trials using RET inhibitors alone or in combination with aromatase inhibitors have struggled with either high toxicity or lack of benefit [1].

In summary, due to its specific role in endocrine resistance as well as the possible correlation with poor prognosis, RET remains a promising therapeutic target in breast cancer [16]. However, analyses of RET expression and association with clinicopathological parameters including survival data in larger patient cohorts are missing. To further investigate the role of RET expression in human breast cancer we performed an immunohistochemical analysis on breast cancer tissue microarrays (TMA) with detailed clinical and survival data. This study is reported according to the reporting recommendations for tumour marker prognostic studies (REMARK) [21].

\section{Material and methods}

\section{Tissue microarray}

Six Tissue Microarrays (TMA) encompassing a total of 1624 breast cancer tissue punches originating from formalin-fixed and paraffin-embedded tumour tissue were used and assembled into a TMA format as previously described $[22,23]$. The specimens derived from patients diagnosed with primary breast cancer between 1985 and 2015 (approximately 90\% of them between 1985 and 1995) at the Institute of Pathology and the private Institute Boss and Spichtin, Switzerland. Due to loss of tissue on individual punches, a total of 990 samples could be evaluated. The loss of tissue is explained by the fact that the TMA have already been used multiple times for various scientific projects and therefore some of the punches are depleted. Additionally, not all tissue punches do indeed contain cancer tissue, but rather benign surrounding tissue, which could not be included in our analysis. Histopathological data was obtained from the individual pathology reports while clinical and survival data were extracted from the hospital database, Cancer Registry of Basel or from the patients' attending physicians. Ethical standards and patients' confidentiality were ensured and in line with regulations of the local institutional review board (Ethikkomission Nordwest- und Zentralschweiz, EKNZ 2014-397) and data safety laws.

\section{Immunohistochemistry}

For immunohistochemical staining, $4 \mu \mathrm{m}$ sections of the TMA blocks were incubated for $12 \mathrm{~min}$ with the polyclonal membranous and cytoplasmatic anti-RET antibody (Clone ab133710, Abcam, Cambridge, UK) in a dilution of 1:50 after heat induced antigen retrieval with citrate buffer at $\mathrm{pH} 6$ for 16 min. Standard-technique for Benchmark Ultra with optiView system was employed. Counterstaining was performed with hematoxylin solution. For Ki-67 (Clone IR626, Dako, Santa Clara, CA, USA) immunostaining was performed on Benchmark Ultra with optiView system. ER, Progesterone Receptor (PR) and HER2 were stained and scored as previously described [24]. For $88 \%$ of the breast cancer cases, ER, PR and HER2 were evaluated on the TMA punches, for the other $12 \%$, these markers were evaluated on whole slide sections of the donor blocks.

The analysis of RET expression was performed by two observers (RM and SM), both blinded to the histopathological, clinical and survival data. The RET expression was scored as [24]: $0=$ absent staining, $1=$ weak intensity, $2=$ intermediate intensity, $3=$ strong intensity (Fig. 1). For the statistical analysis, the score was dichotomised into absent staining and weak intensity (RET negative) versus intermediate and strong intensity (RET positive). Since the staining was evenly distributed across all tumour cells per cancer sample, the proportion of stained tumour cells was not assessed.

\section{Statistical analysis}

Statistical analyses for categorical and non-categorical variables were performed using Fisher's Exact and -Chi-squared tests, respectively. Overall survival was calculated using the Kaplan-Meier method and differences between groups assessed using log-rank tests. Univariate and multivariate analyses for overall survival on clinicopathologic parameters and RET expression were performed using the Cox proportional hazards regression model. Hazard ratios and corresponding 95\% confidence intervals were estimated. All tests were two-sided. $P$-values $<0.05$ were considered statistically 

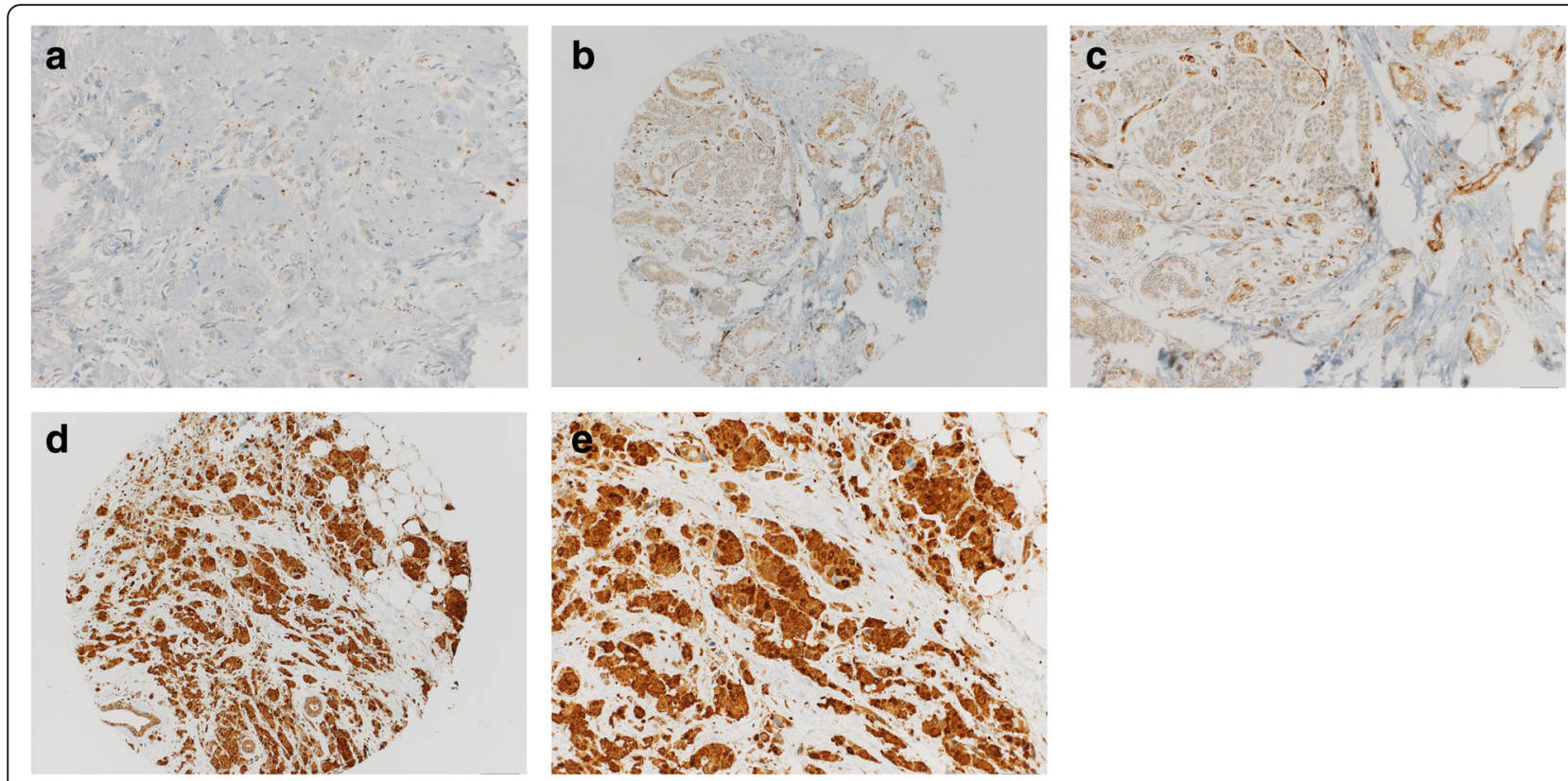

Fig. 1 Five representative photographs of breast cancer tissue punches with immunohistochemical staining of breast cancer cells for RET a: absent staining (0), Magnification 200x; b: weak intensity (1+), Magnification 100x; c: weak intensity (1+), Magnification 200x; d: strong intensity (3+), Magnification 100x; e: strong intensity (3+), Magnification 200x

significant. All analyses were performed using Graphpad Prism 6.0 (Graphpad Software, Inc., La Jolla, CA), SPSS version 20 (IBM, Armonk, NY) or R v3.4.2.

\section{Results}

The mean age of all 990 evaluable patients was 64 years (SD +/ 14) at the time of diagnosis and mean follow up time was 80.8 months (range 1-263). Most of the tumours (78.4\%) were less than $5 \mathrm{~cm}$ in diameter (T1-T2), without lymph node involvement at the time of diagnosis $(51.3 \%)$ and could be allocated to the intrinsic luminal B subtype (53.0\%).

The relatively high proportion of luminal B subtype cancers in our population could be partly due to the low threshold of Ki-67at $\geq 14 \%$ and the fact that Ki-67 was evaluated on the TMA tissue punches, which does not account for heterogeneity of Ki-67 distribution and might have led to an overestimation of Ki-67 expressing cells in some cancers. Other than that, there is no obvious explanation for the high incidence of luminal B subtypes.

Detailed demographic information of the patients can be found in Table 1.

The expression of RET was significantly associated with the expression of ER $(p<0.0001$, Table 2). No significant association of RET expression with tumour size, patient's age, tumour grade and AJCC primary tumour staging system (TNM) such as tumour size (pT) and lymph node involvement $(\mathrm{pN})$ was identified. Moreover, no significant association was found between RET expression and the expression of HER2 as well as the proliferation marker Ki-67 (Table 2).
Looking at the breast cancer intrinsic subtypes as defined by the St. Gallen consensus conference [25], RET expression differed significantly between the five subtypes. The lowest expression was observed in basal-like subtype (31.2\%) followed by HER2 type (36.4\%), luminal B subtype (HER2-negative) (45.3\%) and luminal A subtype (46.0\%). Of all intrinsic subtypes, the luminal B HER2-positive subtype showed the highest expression rate $(48.9 \%, p=0.001$, Table 3). In summary, ER expressing subtypes show a RET expression in $45-46 \%$ of cases, while ER-negative subtypes express RET in only $31-36 \%$ of cases.

In the univariate survival analysis, RET expression had no significant impact on overall survival (OS) of breast cancer patients $(p=0.87)$ In particular, subgroup analysis of intrinsic subtypes revealed no correlation of RET expression with overall survival (Table 4, Fig. 1). For multivariate analysis, we adjusted for grade, tumour size (pT) and lymph node status $(\mathrm{pN})$, age and intrinsic subtypes. We were able to confirm that age $(p<0.0001)$, tumour size (pT) $(p<0.0001)$, lymph node involvement $(\mathrm{pN})(p<0.0001)$ and tumour grade $(p<$ $0.0001)$ were independent prognostic factors and correlated with worse overall survival. Importantly, RET expression had no significant impact on overall survival and is thus not a prognostic factor in human breast cancer in our collective $(p=0.79$, Table 5, Fig. 2).

\section{Discussion}

In the present study, we analysed the role of RET expression in a large cohort of 990 primary breast cancer cases and correlated the expression with clinicopathological 
Table 1 Basic demographic data of all evaluable breast cancer cases $(n=990)$

\begin{tabular}{|c|c|c|}
\hline \multirow{4}{*}{$\begin{array}{l}\text { Mean tumour size }(\mathrm{mm}) \pm \mathrm{SD} \\
\text { Mean age at diagnosis (years) } \pm \mathrm{SD}\end{array}$} & \multicolumn{2}{|l|}{$32 \pm 18$} \\
\hline & \multicolumn{2}{|l|}{$64 \pm 14$} \\
\hline & Number & Percentage \\
\hline & (n) & $(\%)$ \\
\hline \multicolumn{3}{|l|}{ Tumour stage } \\
\hline pT1 & 236 & 23.8 \\
\hline pT2 & 541 & 54.6 \\
\hline pT3 & 85 & 8.6 \\
\hline pT4 & 127 & 12.8 \\
\hline NA & 1 & 0.2 \\
\hline \multicolumn{3}{|l|}{ Lymph node involvement } \\
\hline pNO & 508 & 51.3 \\
\hline $\mathrm{pN} 1$ & 370 & 37.4 \\
\hline $\mathrm{pN} 2$ & 98 & 9.9 \\
\hline $\mathrm{pN} 3$ & 8 & 0.8 \\
\hline NA & 6 & 0.6 \\
\hline \multicolumn{3}{|l|}{ Tumour grade } \\
\hline 1 & 206 & 20.8 \\
\hline 2 & 354 & 35.8 \\
\hline 3 & 429 & 43.3 \\
\hline NA & 1 & 0.1 \\
\hline \multicolumn{3}{|l|}{ Histologic subtype } \\
\hline Invasive ductal & 739 & 74.6 \\
\hline Invasive lobular & 107 & 10.8 \\
\hline Mucinous & 25 & 2.5 \\
\hline Apocrine & 19 & 1.9 \\
\hline Cribriform & 32 & 3.2 \\
\hline Others & 65 & 6.6 \\
\hline NA & 3 & 0.4 \\
\hline \multicolumn{3}{|l|}{ Intrinsic subtype } \\
\hline Luminal A-like (ER ${ }^{+}$and/or $\left.P R^{+}, H E R 2^{-}, K i-67<14 \%\right)$ & 124 & 12.5 \\
\hline Luminal B-like (HER2-negative) (ER ${ }^{+}$and/or $\left.P R^{+}, H E R 2^{-}, K i-67 \geq 14 \%\right)$ & 435 & 43.9 \\
\hline Luminal B-like (HER2-positive) (ER and/or $P R^{+}, H E R 2^{+}$) & 90 & 9.1 \\
\hline HER2 type $\left(E R^{-}, P R^{-}, H E R 2^{+}\right)$ & 77 & 7.8 \\
\hline Basal-like $\left(E R^{-}, P R^{-}, H E R 2^{-}\right)$ & 260 & 26.3 \\
\hline NA & 4 & 0.4 \\
\hline
\end{tabular}

parameters and survival data. We were able to demonstrate a clear correlation of RET expression with ER expression. Importantly, our data suggests that RET expression has no impact on overall survival and thus is not a prognostic factor in human breast cancer.

Since its initial discovery RET has increasingly gained importance in multiple cancer types including breast cancer [12, 26-31]. While RET expression in pancreatic cancer has been consistently reported to correlate with poor survival [26-28] results regarding survival in breast cancer are not entirely consistent [16] and only a few reports using human tissue exist. Gatelli et al. [16] examined RET expression in 89 breast cancer patients. They could demonstrate a correlation of high RET expression with larger tumour size as well as with a decreased metastasis-free and overall survival. Morandi et al. [19] analysed the RET co-receptor ligand GDNF and its signalling pathway in a GDNF-response gene set and correlated it to a dataset of 81 ER positive breast cancer patients as well as 597 breast cancer samples from "The 
Table 2 Association between RET expression and clinicopathological parameters

\begin{tabular}{|c|c|c|c|c|c|}
\hline \multirow{2}{*}{$\begin{array}{l}\text { Clinicopathologic parameter } \\
\text { Mean tumour size }(\mathrm{mm}) \pm S D\end{array}$} & \multicolumn{2}{|c|}{ RET-positive } & \multicolumn{2}{|c|}{ RET-negative } & \multirow{2}{*}{$\begin{array}{r}p \text { value } \\
0.309\end{array}$} \\
\hline & \multicolumn{2}{|c|}{$31 \pm 17$} & \multicolumn{2}{|c|}{$32 \pm 18$} & \\
\hline \multirow[t]{2}{*}{ Mean age at diagnosis (years) $\pm S D$} & \multicolumn{2}{|c|}{$64 \pm 14$} & \multicolumn{2}{|c|}{$64 \pm 14$} & 0.550 \\
\hline & (n) & $(\%)$ & (n) & (\%) & \\
\hline Tumour stage & & & & & 0.546 \\
\hline pT1 & 99 & 41.9 & 137 & 58.1 & \\
\hline pT2 & 224 & 41.4 & 317 & 58.6 & \\
\hline pT3 & 39 & 45.9 & 46 & 54.1 & \\
\hline pT4 & 46 & 36.2 & 81 & 63.8 & \\
\hline NA & 1 & 100 & 0 & 0 & \\
\hline Lymph node involvement & & & & & 0.468 \\
\hline pNO & 201 & 39.6 & 307 & 60.4 & \\
\hline pN1 & 163 & 44.1 & 207 & 55.9 & \\
\hline pN2 & 37 & 37.8 & 61 & 62.2 & \\
\hline pN3 & 4 & 50.0 & 4 & 50.0 & \\
\hline NA & 4 & 66.7 & 2 & 33.3 & \\
\hline Tumour grade & & & & & 0.401 \\
\hline 1 & 91 & 44.2 & 115 & 55.8 & \\
\hline 2 & 137 & 38.7 & 217 & 61.3 & \\
\hline 3 & 181 & 42.2 & 248 & 57.8 & \\
\hline NA & 0 & 0 & 1 & 100 & \\
\hline Oestrogen receptor & & & & & $<0.0001$ \\
\hline $\mathrm{ER}^{+}$ & 295 & 46.0 & 347 & 54.0 & \\
\hline $\mathrm{ER}^{-}$ & 114 & 32.8 & 234 & 67.2 & \\
\hline HER2 & & & & & 0.666 \\
\hline $\mathrm{HER}^{+}$ & 72 & 43.1 & 95 & 56.9 & \\
\hline HER2 ${ }^{-}$ & 337 & 40.9 & 486 & 59.1 & \\
\hline Ki67 & & & & & 0.635 \\
\hline Ki67 $7^{\text {-high }}$ & 331 & 41.7 & 463 & 58.3 & \\
\hline Ki67 $7^{\text {-low }}$ & 75 & 39.5 & 115 & 60.5 & \\
\hline NA & 3 & 50.0 & 3 & 50.0 & \\
\hline
\end{tabular}

Table 3 Association between RET expression and breast cancer intrinsic subtype

\begin{tabular}{|c|c|c|c|c|c|}
\hline \multirow[t]{2}{*}{ Intrinsic subtype } & \multicolumn{2}{|c|}{ RET-positive } & \multicolumn{2}{|c|}{ RET-negative } & \multirow{2}{*}{$\begin{array}{c}p \text { value } \\
0.001\end{array}$} \\
\hline & $(n)$ & $(\%)$ & $(n)$ & $(\%)$ & \\
\hline Luminal A (ER ${ }^{+}$and/or PR $\left.R^{+}, H E R 2^{-}, K i-67<14 \%\right)$ & 57 & 46.0 & 67 & 54.0 & \\
\hline Luminal B (HER2-negative) (ER and/or PR+ ${ }^{+}, H E R 2^{-}, K i-67 \geq 14 \%$ ) & 197 & 45.3 & 238 & 54.7 & \\
\hline Luminal B (HER2-positive) (ER and/or $P R^{+}, H E R 2^{+}$) & 44 & 48.9 & 46 & 51.1 & \\
\hline HER2 type (ER $\left., P R^{-}, H E R 2^{+}\right)$ & 28 & 36.4 & 49 & 63.6 & \\
\hline Basal-like $\left(E R^{-}, P R^{-}, H E R 2^{-}\right)$ & 81 & 31.2 & 179 & 68.8 & \\
\hline NA & 2 & 50.0 & 2 & 50.0 & \\
\hline
\end{tabular}


Table 4 Univariate analyses for all cases, and by intrinsic subtype, for the effect of RET expression on overall survival

\begin{tabular}{|c|c|c|}
\hline RET expression, all cases & Hazard Ratio $(95 \% \mathrm{Cl})$ & $p$ value \\
\hline RET positivity & $1.02(0.82-1.26)$ & 0.87 \\
\hline \multicolumn{3}{|l|}{ RET positivity, by intrinsic subtype } \\
\hline Luminal A (ER ${ }^{+}$and/or $\left.P R^{+}, H E R 2^{-}, K i-67<14 \%\right)$ & $1.54(0.79-3.00)$ & 0.21 \\
\hline Luminal B (HER2-negative) (ER ${ }^{+}$and/or PR+ $\left.{ }^{+}, H E R 2^{-}, K i-67 \geq 14 \%\right)$ & $0.99(0.72-1.36)$ & 0.95 \\
\hline Luminal B (HER2-positive) (ER ${ }^{+}$and/or $P R^{+}, H E R 2^{+}$) & $1.00(0.52-1.95)$ & 0.99 \\
\hline HER2 type (ER $\left., P R^{-}, H E R 2^{+}\right)$ & $1.46(0.73-2.92)$ & 0.28 \\
\hline Basal-like $\left(E R^{-}, P R^{-}, H E R 2^{-}\right)$ & $0.86(0.54-1.37)$ & 0.52 \\
\hline \multicolumn{3}{|l|}{ RET positivity, by ER status } \\
\hline$E R^{+}$ & $1.06(0.82-1.38)$ & 0.65 \\
\hline $\mathrm{ER}^{-}$ & $1.05(0.72-1.52)$ & 0.81 \\
\hline
\end{tabular}

Cancer Genome Atlas" [32] Not only did they find a significant higher GDNF score in Luminal B breast cancer subtype in both data sets, but also a decreased distant metastasis free survival, relapse free survival and overall survival in this subtype [19]. Together with the fact that the Luminal B subtype is characterised by poorer prognosis within ER positive breast cancers [33], these results suggest a correlation of an activated GDNF signalling cascade resulting in RET activation. Concordantly, we found high RET expression rates in the Luminal B breast cancer subtypes. Another study by Griseri et al. [34] performed a $R E T$ genotyping association study in a cohort of $93 \mathrm{ER}$ positive breast cancers and also found a statistically significant association of RET over-expression with poor prognosis.

While our data did not confirm an impact of RET expression on prognosis in ER positive breast cancer, we were able to reproduce the association of RET and ER expression [4]. This correlation was underlined in the past by the discovery of a cross-talk of the RET and ER signalling cascade [6]. While RET and GFR $\alpha$ seem to be

Table 5 Multivariate analysis for the effect of clinicopathologic parameters and RET expression on overall survival

\begin{tabular}{lll}
\hline Clinicopathologic parameter & Hazard Ratio (95\% Cl) & $p$-value \\
\hline Age (per 1-year) & $1.04(1.03-1.05)$ & $<0.0001$ \\
Tumour size (pT) & $1.29(1.14-1.45)$ & $<0.0001$ \\
Lymph node involvement (pN) & $1.47(1.25-1.73)$ & $<0.0001$ \\
Tumour grade (BRE) & $1.77(1.50-2.10)$ & $<0.0001$ \\
Intrinsic subtype & & \\
$\quad$ Luminal A & 1 & 0.81 \\
$\quad$ Luminal B (HER2-negative) & $0.96(0.66-1.39)$ & 0.92 \\
$\quad$ Luminal B (HER2-positive) & $1.03(0.64-1.65)$ & 0.58 \\
$\quad$ HER 2 type & $0.86(0.51-1.45)$ & 0.09 \\
$\quad$ Basal-like & $1.43(0.94-2.18)$ & \\
RET expression & & 0.79 \\
$\quad$ RET-positive & $1.03(0.83-1.28)$ & \\
\hline
\end{tabular}

direct target genes for oestrogen signalling, RET signalling in turn increases ER independent transcriptional activation of ER $\alpha$ target genes [6]. Further exploration revealed that RET plays a significant role in the resistance of cancer cells to endocrine treatment [1]. By expressing RET, the tumour cells develop de novo resistance and become resistant after an initial response [7, 14, 15]. Plaza-Menacho et al. [14] have shown that RET downregulation results in a 6.2-fold increase in sensitivity of the ER positive MCF7 cell line to the antiproliferative effect of the selective ER modulator Tamoxifen. Moreover, GDNF stimulation caused resistance to the drug and targeting RET restored Tamoxifen resistance [14]. A consecutive TMA study of 245 primary human breast cancers showed an association between RET expression and recurrent disease after adjuvant Tamoxifen treatment [14].

In summary, the crosstalk between RET and ER is important in the development of endocrine resistance and specifically targeting RET within combination treatment regimens might help to restore endocrine resistance in ER positive tumours. Since a majority (70\%) of breast cancers are ER positive [35], strategies are needed to address this therapeutic problem [7, 36].

While specific RET inhibitors are only beginning to emerge, two different types of inhibitory agents are currently evaluated within preclinical and clinical trials in breast cancer [1]. Small molecule tyrosine kinase inhibitors are therapeutic substances, which are not exclusively targeting RET but also other tyrosine kinases [37]. Some of them at least partially managed to overcome endocrine resistance in breast cancer cell lines and mouse models [15, 18-20]. However, clinical Phase I and II studies struggle with a lack of benefit or toxicity when using such inhibitors, for example Sorafenib, Imatinib or Sunitinib, as monotherapies [38-41]. Combination therapy of Sorafenib with endocrine therapy as well as Sunitinib with chemotherapy showed more promising results but further data is needed [42]. Vadentanib monotherapy as well as its use within combination 


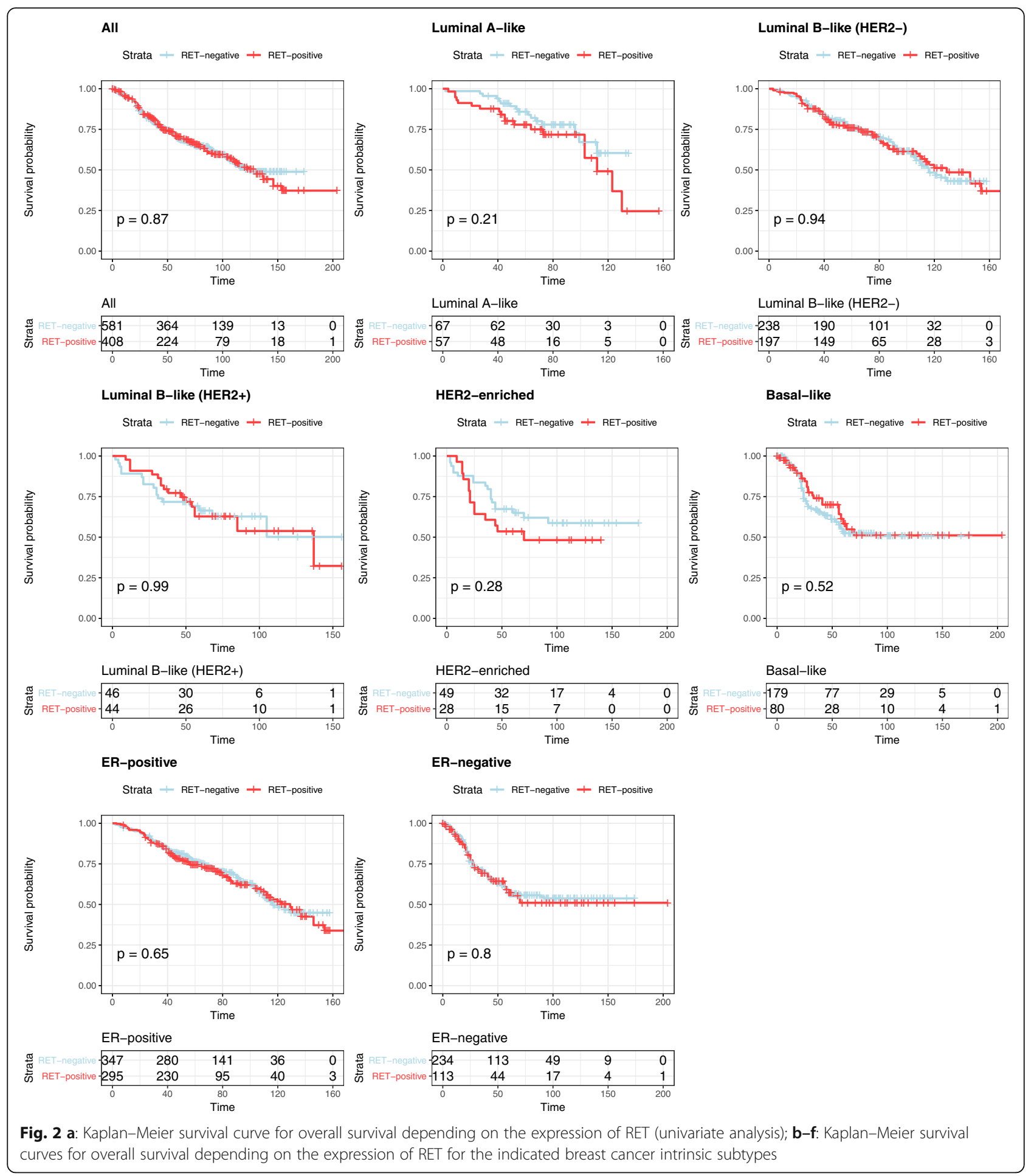

schemes was well tolerated but failed to demonstrate improved survival [43]. Several clinical trials are ongoing [1]. However, none of these drugs have been approved for a cohort with an actionable alteration involving RET [44], stressing the importance of defining patients who might benefit from RET inhibition.
Recent studies identified more specific and potent RET inhibitors such as Sitravatinib, which are currently evaluated in thyroid and non-small cell lung cancer [44, 45]. These trials will hopefully enlighten the debate about their potential benefits and show a reduced toxicity. 
While the results of small molecule tyrosine inhibitors are difficult to interpret, inhibition of RET downstream signalling elements, shared with other signalling pathways [14], seem to be currently more promising. The ER receptor contains two transcription active domains, activation function (AF)-1 and AF-2 [7]. While AF-2 activity is dependent on estrogen binding, AF-1 is regulated by phosphorylation mediated via extracellular signal-regulated kinases (ERK) 1/2, phosphatidylinositol 3-kinase (PI3K)/AKT, Protein kinase cAMP-dependent (PKA), cyclin A/E-CDK2, P21-Activated Kinase (PAK)1, cyclin-dependent kinase (CDK)7/Transcription factor II Human (TFIIH), p90RSK or p38 pathways. These are activated themselves by a large number of receptor tyrosine kinases including several growth factor receptor families $[1,7]$. The activation of RET by GDNF in this context, has been demonstrated to increase ER $\alpha$ phosphorylation and estrogen-independent transcriptional activation of ER $\alpha$ target genes [14]. Interestingly, the RET downstream signalling in GDNF-treated MCF7 cells happens to a higher extent via the mechanistic target of Rapamycin (mTOR)/p70S6K pathway than the ERK1/2 and PI3K/ AKT pathway [14]. This is confirmed by the fact, that RET downstream signalling was blocked with mTOR inhibitor Rapamycin, while a chemical inhibition of AKT and ERK1/2 had no impact [14]. By adding the mTOR inhibitor Everolimus to an aromatase inhibitor the BOLERO2 trial, managed to show an improved median progression-free survival of 6 months in ER positive breast cancer [46]. Therefore, current evidence suggests downstream elements of RET as possible therapeutic targets.

A general limitation of our study is that older samples might have suffered from loss of protein antigenicity, which might have affected the immunohistochemical staining outcome. A further point which needs to be mentioned is the method of defining the molecular subtypes. We used the definition of the St. Gallen Consensus Conference, which only provide an approximate definition of intrinsic subtypes and might lead to a underestimation of the impact of RET in the triple negative subtype [25, 47]. Another limiting factor is related to the follow-up in this study. Luminal A subtypes and T1/2 N0 stage cancers have a less aggressive course of disease and might recur even after 10 years. These late recurrences might therefore not be represented in our study due to the mean follow up period of 6.7 years.

A final limiting fact is the long recruitment period of 31 years which might have affected definitions of histopathological grading and staging. The same accounts for changing treatment regimens over time, which could have influenced the survival data.

\section{Conclusion}

In summary, the results of our study confirm current knowledge that RET is an important element in ER positive breast cancer. However, our results, derived from a large breast cancer patient cohort with annotated clinicopathological data, underline the uncertainty regarding the prognostic impact of RET expression on patient survival in breast cancer and stresses the importance of further research. In light of this, further clinical trials identifying an adequate patient subgroup which might profit from RET inhibition as well as further studies investigating the impact of RET expression on patient outcome in breast cancer are clearly needed.

\begin{abstract}
Abbreviations
AF: Actviation Function; AJCC: American Joint Committee on Cancer; CDK: Cyclin-dependent kinase; EKNZ: Ethikkomission Nordwest- und Zentralschweiz; ER: Estrogen Receptor; ERK: Extracellular signal-regulated kinases; GDNF: E glial cell line-derived neurotrophic factor; GFRa1-4: GDNF family a-receptors; HER2: Human Epidermal Growth Factor Receptor 2; mTOR: Mechanistic Target of Rapamycin; PAK: P21-Activated Kinase; PIK3: Phosphatidylinositol 3-kinase; PKA: Protein kinase CAMP-dependent; PR: Progesterone Receptor; REMARK: Reporting recommendations for tumourmarker prognostic studies; RET: Rearranged during Transfection; RTK: Receptor tyrosine kinase; SD: Standard Deviation; TFIIH: Transcription factor II Human; TMA: Tissue Microarry
\end{abstract}

\section{Acknowledgments}

We would like to thank Petra Hirschmann for the immunohistochemical staining of the TMA slides as well as Martin Portmann for the slide scanning.

\section{Funding}

This work was supported by the Holcim Foundation for the Advancement of Scientific Research, the Claudia von Schilling Foundation for Breast Cancer Research, the Freiwillige Akademische Gesellschaft Basel and the

Huggenberger-Bischoff Foundation. The funding bodies provided the means to perform the study, but had no role in the design of the study, or the collecting, analysing or interpretation of the data and writing of the manuscript. SP is funded by Swiss National Science Foundation (Ambizione grant number PZOOP3_168165).

\section{Availability of data and materials}

The datasets used and/or analysed during the current study are available from the corresponding author on reasonable request.

\section{Authors' contributions}

RM did the immunohistochemical evaluation, contributed to the figures and wrote the manuscript; SDS planned and designed the study, identified the patient collective and critically reviewed the manuscript; SP and CKYN did the statistical analysis, wrote the statistical part, contributed to the figures and critically revised the manuscript; EK established the tissue microarray and critically reviewed the manuscript; JZ, SD, PG, HH, EM, RAD, WP W helped to design the study and critically reviewed the manuscript; SM planned, designed and sponsored the study, supervised the immunohistochemical staining, did the immunohistochemical evaluation, contributed to the figures and reviewed the manuscript. All authors read and approved the final manuscript

\section{Ethics approval and consent to participate}

Ethical standards and patients' confidentiality were ensured and in line with regulations of the local institutional review board and data safety laws. The study proposal was submitted to and approved by the ethics committee of northern and central Switzerland (Ethikkomission Nordwest- und Zentralschweiz, (EKNZ), Nr. 2014397). The EKNZ waived the need for patient consent to participate in this study.

Consent for publication

Not applicable.

Competing interests

The authors declare that they have no competing interests. 


\section{Publisher's Note}

Springer Nature remains neutral with regard to jurisdictional claims in published maps and institutional affiliations.

\section{Author details}

'Department of Surgery, University Hospital Basel, Spitalstrasse 21, 4031 Basel, Switzerland. ${ }^{2}$ Institute of Pathology, University Hospital Basel, Schoenbeinstrasse 40, 4031 Basel, Switzerland. Institute of Pathology, Klinikum Leverkusen, Am Gesundheitspark 11, 51375 Leverkusen, Germany.

Received: 5 June 2018 Accepted: 28 December 2018 Published online: 08 January 2019

\section{References}

1. Morandi A, Plaza-Menacho I, Isacke CM. RET in breast cancer: functional and therapeutic implications. Trends Mol Med. 2011;17(3):149-57.

2. Ichihara M, Murakumo Y, Takahashi M. RET and neuroendocrine tumors. Cancer Lett. 2004:204(2):197-211.

3. Mizuno T, Iwamoto KS, Kyoizumi S, Nagamura H, Shinohara T, Koyama K, Seyama T, Hamatani K. Preferential induction of RET/PTC1 rearrangement by X-ray irradiation. Oncogene. 2000;19(3):438-43.

4. Esseghir S, Todd SK, Hunt T, Poulsom R, Plaza-Menacho I, Reis-Filho JS, Isacke CM. A role for glial cell derived neurotrophic factor induced expression by inflammatory cytokines and RET/GFR alpha 1 receptor upregulation in breast cancer. Cancer Res. 2007;67(24):11732-41.

5. Grieco M, Santoro M, Berlingieri MT, Melillo RM, Donghi R, Bongarzone I, Pierotti MA, Della Porta G, Fusco A, Vecchio G. PTC is a novel rearranged form of the ret proto-oncogene and is frequently detected in vivo in human thyroid papillary carcinomas. Cell. 1990;60(4):557-63.

6. Boulay A, Breuleux M, Stephan C, Fux C, Brisken C, Fiche M, Wartmann M, Stumm M, Lane HA, Hynes NE. The ret receptor tyrosine kinase pathway functionally interacts with the ERalpha pathway in breast cancer. Cancer Res. 2008:68(10):3743-51.

7. Ali S, Coombes RC. Endocrine-responsive breast cancer and strategies for combating resistance. Nat Rev Cancer. 2002;2(2):101-12.

8. Slamon DJ, Godolphin W, Jones LA, Holt JA, Wong SG, Keith DE, Levin WJ, Stuart SG, Udove J, Ullrich A, et al. Studies of the HER-2/neu proto-oncogene in human breast and ovarian cancer. Science. 1989;244(4905):707-12.

9. Reis-Filho JS, Pinheiro C, Lambros MB, Milanezi F, Carvalho S, Savage K, Simpson PT, Jones C, Swift S, Mackay A, et al. EGFR amplification and lack of activating mutations in metaplastic breast carcinomas. J Pathol. 2006:209(4):445-53.

10. Reis-Filho JS, Simpson PT, Turner NC, Lambros MB, Jones C, Mackay A, Grigoriadis A, Sarrio D, Savage K, Dexter T, et al. FGFR1 emerges as a potential therapeutic target for lobular breast carcinomas. Clin Cancer Res. 2006;12(22):6652-62.

11. Thomas RK, Baker AC, Debiasi RM, Winckler W, Laframboise T, Lin WM, Wang M, Feng W, Zander T, MacConaill L, et al. High-throughput oncogene mutation profiling in human cancer. Nat Genet. 2007:39(3):347-51.

12. Kan ZY, Jaiswal BS, Stinson J, Janakiraman V, Bhatt D, Stern HM, Yue P, Haverty PM, Bourgon R, Zheng JB, et al. Diverse somatic mutation patterns and pathway alterations in human cancers. Nature. 2010;466(7308):869-U103.

13. Tozlu S, Girault I, Vacher S, Vendrell J, Andrieu C, Spyratos F, Cohen P, Lidereau R, Bieche I. Identification of novel genes that co-cluster with estrogen receptor alpha in breast tumor biopsy specimens, using a largescale real-time reverse transcription-PCR approach. Endocr Relat Cancer. 2006:13(4):1109-20.

14. Plaza-Menacho I, Morandi A, Robertson D, Pancholi S, Drury S, Dowsett M, Martin LA, Isacke CM. Targeting the receptor tyrosine kinase RET sensitizes breast cancer cells to tamoxifen treatment and reveals a role for RET in endocrine resistance. Oncogene. 2010;29(33):4648-57.

15. Andreucci $E$, Francica $P$, Fearns $A$, Martin LA, Chiarugi $P$, Isacke CM, Morandi A. Targeting the receptor tyrosine kinase RET in combination with aromatase inhibitors in ER positive breast cancer xenografts. Oncotarget. 2016;7:80543-53

16. Gattelli A, Nalvarte I, Boulay A, Roloff TC, Schreiber M, Carragher N, Macleod KK, Schlederer M, Lienhard S, Kenner L, et al. Ret inhibition decreases growth and metastatic potential of estrogen receptor positive breast cancer cells. EMBO Mol Med. 2013;5(9):1335-50.

17. Morandi A, Isacke CM. Targeting RET-interleukin-6 crosstalk to impair metastatic dissemination in breast cancer. Breast Cancer Res. 2014;16(1):301.
18. Spanheimer PM, Park JM, Askeland RW, Kulak MV, Woodfield GW, De Andrade JP, Cyr AR, Sugg SL, Thomas A, Weigel RJ. Inhibition of RET increases the efficacy of antiestrogen and is a novel treatment strategy for luminal breast cancer. Clin Cancer Res. 2014;20(8):2115-25.

19. Morandi A, Martin LA, Gao Q, Pancholi S, Mackay A, Robertson D, Zvelebil M, Dowsett M, Plaza-Menacho I, Isacke CM. GDNF-RET signaling in ERpositive breast cancers is a key determinant of response and resistance to aromatase inhibitors. Cancer Res. 2013;73(12):3783-95.

20. Spanheimer PM, Cyr AR, Gillum MP, Woodfield GW, Askeland RW, Weigel RJ. Distinct pathways regulated by RET and estrogen receptor in luminal breast cancer demonstrate the biological basis for combination therapy. Ann Surg. 2014;259(4):793-9.

21. Altman DG, McShane LM, Sauerbrei W, Taube SE. Reporting recommendations for tumor marker prognostic studies (REMARK): explanation and elaboration. PLoS Med. 2012;9(5):e1001216.

22. Bubendorf L, Nocito A, Moch H, Sauter G. Tissue microarray (TMA) technology: miniaturized pathology archives for high-throughput in situ studies. J Pathol. 2001;195(1):72-9.

23. Sepe R, Piscuoglio S, Quintavalle C, Perrina V, Quagliata L, Formisano U, Terracciano LM, Fusco A, Pallante P. HMGA1 overexpression is associated with a particular subset of human breast carcinomas. J Clin Pathol. 2016;69(2):117-21.

24. Tapia C, Schraml P, Simon R, Al-Kuraya KS, Maurer R, Mirlacher M, Novotny $\mathrm{H}$, Spichtin $\mathrm{H}$, Mihatsch MJ, Sauter G. HER2 analysis in breast cancer: reduced immunoreactivity in FISH non-informative cancer biopsies. Int J Oncol. 2004;25(6):1551-7.

25. Goldhirsch A, Wood WC, Coates AS, Gelber RD, Thurlimann B, Senn HJ, Panel M. Strategies for subtypes--dealing with the diversity of breast cancer: highlights of the St. Gallen international expert consensus on the primary therapy of early breast Cancer 2011. Ann Oncol. 2011;22(8):1736-47.

26. Ito $Y$, Okada $Y$, Sato M, Sawai H, Funahashi H, Murase T, Hayakawa T, Manabe T. Expression of glial cell line-derived neurotrophic factor family members and their receptors in pancreatic cancers. Surgery. 2005;138(4):788-94

27. Sawai H, Okada Y, Kazanjian K, Kim J, Hasan S, Hines OJ, Reber HA, Hoon DS, Eibl G. The G691S RET polymorphism increases glial cell line-derived neurotrophic factor-induced pancreatic cancer cell invasion by amplifying mitogen-activated protein kinase signaling. Cancer Res. 2005;65(24):11536-44.

28. Zeng Q, Cheng Y, Zhu Q, Yu Z, Wu X, Huang K, Zhou M, Han S, Zhang Q. The relationship between overexpression of glial cell-derived neurotrophic factor and its RET receptor with progression and prognosis of human pancreatic cancer. J Int Med Res. 2008;36(4):656-64.

29. Iwahashi N, Murakami H, Nimura Y, Takahashi M. Activation of RET tyrosine kinase regulates interleukin-8 production by multiple signaling pathways. Biochem Biophys Res Commun. 2002;294(3):642-9.

30. Narita N, Tanemura A, Murali R, Scolyer RA, Huang S, Arigami T, Yanagita S, Chong KK, Thompson JF, Morton DL, et al. Functional RET G691S polymorphism in cutaneous malignant melanoma. Oncogene. 2009;28(34):3058-68.

31. Ohshima Y, Yajima I, Takeda K, lida M, Kumasaka M, Matsumoto Y, Kato M. C-RET molecule in malignant melanoma from oncogenic RET-carrying transgenic mice and human cell lines. PLoS One. 2010;5(4):e10279.

32. Cancer Genome Atlas N. Comprehensive molecular portraits of human breast tumours. Nature. 2012:490(7418):61-70.

33. Kennecke H, Yerushalmi R, Woods R, Cheang MC, Voduc D, Speers CH, Nielsen TO, Gelmon K. Metastatic behavior of breast cancer subtypes. J Clin Oncol. 2010;28(20):3271-7.

34. Griseri P, Garrone O, Lo Sardo A, Monteverde M, Rusmini M, Tonissi F, Merlano M, Bruzzi P, Lo Nigro C, Ceccherini I. Genetic and epigenetic factors affect RET gene expression in breast cancer cell lines and influence survival in patients. Oncotarget. 2016;7(18):26465-79.

35. Dowsett M, Houghton J, Iden C, Salter J, Farndon J, A'Hern R, Sainsbury R, Baum M. Benefit from adjuvant tamoxifen therapy in primary breast cancer patients according oestrogen receptor, progesterone receptor, EGF receptor and HER2 status. Ann Oncol. 2006;17(5):818-26.

36. Musgrove EA, Sutherland RL. Biological determinants of endocrine resistance in breast cancer. Nat Rev Cancer. 2009;9(9):631-43.

37. Zuercher WJ, Turunen BJ, Lackey KE. Current review of small molecule ret kinase inhibitors. Mini Rev Med Chem. 2010;10(2):138-46.

38. Moreno-Aspitia A, Morton RF, Hillman DW, Lingle WL, Rowland KM Jr, Wiesenfeld M, Flynn PJ, Fitch TR, Perez EA. Phase II trial of sorafenib in patients with metastatic breast cancer previously exposed to anthracyclines or taxanes: north central Cancer treatment group and Mayo Clinic trial N0336. J Clin Oncol. 2009;27(1):11-5. 
39. Barrios CH, Liu MC, Lee SC, Vanlemmens L, Ferrero JM, Tabei T, Pivot X, Iwata $H$, Aogi K, Lugo-Quintana R, et al. Phase III randomized trial of sunitinib versus capecitabine in patients with previously treated HER2-negative advanced breast cancer. Breast Cancer Res Treat. 2010;121(1):121-31.

40. Cristofanilli M, Morandi P, Krishnamurthy S, Reuben JM, Lee BN, Francis D, Booser DJ, Green MC, Arun BK, Pusztai L, et al. Imatinib mesylate (Gleevec) in advanced breast cancer-expressing C-kit or PDGFR-beta: clinical activity and biological correlations. Ann Oncol. 2008;19(10):1713-9.

41. Modi S, Seidman AD, Dickler M, Moasser M, D'Andrea G, Moynahan ME, Menell J, Panageas KS, Tan LK, Norton L, et al. A phase II trial of imatinib mesylate monotherapy in patients with metastatic breast cancer. Breast Cancer Res Treat. 2005;90(2):157-63.

42. Isaacs C, Herbolsheimer P, Liu MC, Wilkinson M, Ottaviano Y, Chung GG, Warren R, Eng-Wong J, Cohen P, Smith KL, et al. Phase I/II study of sorafenib with anastrozole in patients with hormone receptor positive aromatase inhibitor resistant metastatic breast cancer. Breast Cancer Res Treat. 2011;125(1):137-43.

43. Clemons MJ, Cochrane B, Pond GR, Califaretti N, Chia SK, Dent RA, Song X, Robidoux A, Parpia S, Warr D, et al. Randomised, phase II, placebocontrolled, trial of fulvestrant plus vandetanib in postmenopausal women with bone only or bone predominant, hormone-receptor-positive metastatic breast cancer (MBC): the OCOG ZAMBONEY study. Breast Cancer Res Treat. 2014;146(1):153-62.

44. Drilon A, Hu ZI, Lai GGY, Tan DSW. Targeting RET-driven cancers: lessons from evolving preclinical and clinical landscapes. Nat Rev Clin Oncol. 2017;15(3):150.

45. Sabari JK, Siau ED, Drilon A. Targeting RET-rearranged lung cancers with multikinase inhibitors. Oncoscience. 2017:4(3-4):23-4.

46. Baselga J, Campone M, Piccart M, Burris HA 3rd, Rugo HS, Sahmoud T, Noguchi S, Gnant M, Pritchard Kl, Lebrun F, et al. Everolimus in postmenopausal hormone-receptor-positive advanced breast cancer. N Engl J Med. 2012;366(6):520-9.

47. Penault-Llorca F, Viale G. Pathological and molecular diagnosis of triple-negative breast cancer: a clinical perspective. Ann Oncol. 2012;23(Suppl 6)vi19-22.

Ready to submit your research? Choose BMC and benefit from:

- fast, convenient online submission

- thorough peer review by experienced researchers in your field

- rapid publication on acceptance

- support for research data, including large and complex data types

- gold Open Access which fosters wider collaboration and increased citations

- maximum visibility for your research: over $100 \mathrm{M}$ website views per year

At $\mathrm{BMC}$, research is always in progress.

Learn more biomedcentral.com/submissions 